\title{
Front Matter: Volume 11886
}

, "Front Matter: Volume 11886," Proc. SPIE 11886, International Conference on X-Ray Lasers 2020, 1188601 (8 July 2021); doi: 10.1117/12.2603507

SPIE. Event: XVII International Conference on X-Ray Lasers, 2020, Online Only 


\section{PROCEEDINGS OF SPIE}

\section{International Conference on $X$-Ray Lasers 2020}

\section{Davide Bleiner}

Editor

\section{8-10 December 2020 Online Only}

Organized by

Davide Bleiner, Empa, Materials Science \& Technology (Switzerland)

David Spichiger, Swiss Chemical Society (Switzerland)

Sponsored by

Empa, Materials Science \& Technology (Switzerland)

Laserlab Europe (European Union)

Elettra Sincrotrone Trieste (Italy)

European X-ray Spectrometry Association (Hungary)

Applied Nanotools (Canada)

Greateyes (Germany)

Lumibird (France)

Luxel (United States)

Rigaku Innovative Technologies (Japan)

XUV Lasers (United States)

Published by

SPIE

\section{Volume 11886}


The papers in this volume were part of the technical conference cited on the cover and title page. Papers were selected and subject to review by the editors and conference program committee. Some conference presentations may not be available for publication. Additional papers and presentation recordings may be available online in the SPIE Digital Library at SPIEDigitalLibrary.org.

The papers reflect the work and thoughts of the authors and are published herein as submitted. The publisher is not responsible for the validity of the information or for any outcomes resulting from reliance thereon.

Please use the following format to cite material from these proceedings:

Author(s), "Title of Paper," in International Conference on X-Ray Lasers 2020, edited by Davide Bleiner, Proc. of SPIE 11886, Seven-digit Article CID Number (DD/MM/YYYY); (DOI URL).

ISSN: 0277-786X

ISSN: 1996-756X (electronic)

ISBN: 9781510646186

ISBN: 9781510646193 (electronic)

Published by

SPIE

P.O. Box 10, Bellingham, Washington 98227-0010 USA

Telephone +1 3606763290 (Pacific Time)

SPIE.org

Copyright @ 2021 Society of Photo-Optical Instrumentation Engineers (SPIE).

Copying of material in this book for internal or personal use, or for the internal or personal use of specific clients, beyond the fair use provisions granted by the U.S. Copyright Law is authorized by SPIE subject to payment of fees. To obtain permission to use and share articles in this volume, visit Copyright Clearance Center at copyright.com. Other copying for republication, resale, advertising or promotion, or any form of systematic or multiple reproduction of any material in this book is prohibited except with permission in writing from the publisher.

Printed in the United States of America by Curran Associates, Inc., under license from SPIE.

Publication of record for individual papers is online in the SPIE Digital Library.

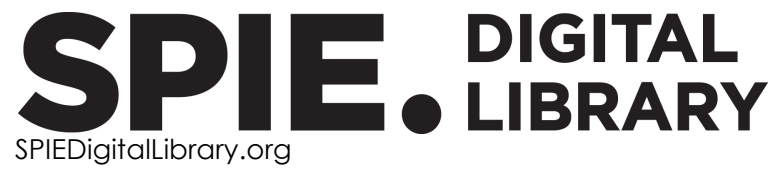

Paper Numbering: A unique citation identifier (CID) number is assigned to each article in the Proceedings of SPIE at the time of publication. Utilization of CIDs allows articles to be fully citable as soon as they are published online, and connects the same identifier to all online and print versions of the publication. SPIE uses a seven-digit CID article numbering system structured as follows:

- The first five digits correspond to the SPIE volume number.

- The last two digits indicate publication order within the volume using a Base 36 numbering system employing both numerals and letters. These two-number sets start with 00, 01, 02, 03, 04, $05,06,07,08,09,0 A, 0 B \ldots$. OZ, followed by 10-1Z, 20-2Z, etc. The CID Number appears on each page of the manuscript. 


\title{
Contents
}

\author{
INTRODUCTION
}

1188602 The science and technology of X-ray lasers: a 2020 update [1 1886-100]

SESSION $1 \quad X$-RAY LASERS ON A TABLETOP: PAST \& PRESENT

1188603 First seeds of X-ray lasers: a tribute to Pierre Jaeglé [1 1886-25]

$1188604 \quad$ X-ray lasers: the evolution from Star Wars to the table-top [1 1886-14]

1188605 A brief history of short wavelength coherent radiation sources [11886-1]

1188606 Demonstration of Multi-Hz repetition rate X-ray lasers at shorter wavelengths [1 1886-32]

SESSION 2 ADVANCED X-RAY LASERS: FROM HIGH-END FACILITY TO TABLETOP

1188607 EMPULSE: a compact terawatt chirped pulse amplification laser for generating coherent $x$-rays [11886-33]

$1188608 \quad$ Update on laser-driven X-ray sources at ELI Beamlines [1 1886-27]

1188609 Inverse compton scattering X-ray source for research, industry and medical applications [11886-16]

11886 OA Tomographic characterization of gas jets for laser-plasma acceleration with increased sensitivity [11886-9]

11886 OB Solid-target seeded soft X-ray laser for short pulses and optical vortex amplification [1 1886-29]

11886 OC 2D-3D multiscale modelling of inhomogeneous plasma amplifiers [1 1886-23]

11886 OD X-ray laser development at the Institute of Laser Engineering, Osaka University with worldwide collaboration [11886-8]

11886 OE An approach for realizing four-wave-mixing experiments stimulated by two-color extreme ultraviolet pulses [1 1886-28]

11886 OF Four-wave mixing with multi-color laser in extreme ultraviolet region [1 1886-7] 
11886 OG Efficient extreme-ultraviolet multi-band high-order wave mixing in silica [1 1886-21]

$11886 \mathrm{OH} \quad$ Ultra-strong attosecond laser focus produced by a relativistic-flying parabolic mirror [1 1886-19]

$11886 \mathrm{Ol} \quad$ Temporal and spectral control of the X-ray pulses in a resonant medium with a modulated transition frequency [11886-17]

SESSION $3 \quad$ ADVANCES ON X-RAY LASER OPTICS \& METHODS

11886 OJ Phase-Contrast Tomography with X-ray Hartmann wavefront sensor [1 1886-10]

11886 OK Numerical investigation of the effect of number of zones on Fresnel Zone Plates imaging performance under different coherence conditions [1 1886-39]

$11886 \mathrm{OL} \quad$ Single-shot wavefront characterization of high topological charge extreme-ultraviolet vortex [11886-4]

11886 OM On the use of multilayer Lave lenses with X-ray free electron lasers [1 1886-20]

11886 ON Temporal characterization of a plasma-based seeded XUV laser using a laser-dressed photoionization technique [11886-30]

$1188600 \quad$ Single-shot picosecond resolution Fourier transform holographic microscopy with large field of view using a compact soft X-ray laser [11886-31]

11886 OP Multiscale lensless imaging with a plasma X-ray laser [1 1886-34]

$118860 Q \quad$ Phase-contrast imaging with laser-plasma-accelerator betatron sources [1 1886-5]

SESSION 4 LABORATORY X-RAY LASERS: PRESENT \& FUTURE APPLICATIONS

11886 OR Short pulse soft X-ray laser ablation research [11886-2]

11886 OS Energy and charge distribution of Si ions in EUV ablation plasma [1 1886-26]

11886 OT The role of photo-ionization in extreme ultraviolet ablation interactions [1 1886-3]

11886 OU Coherent pore-scale imaging: phase contrast and ptychography [1 1886-12]

11886 OV Composition analysis of boron carbide coatings prepared by reactive sputtering with nitrogen [1 1886-22]

11886 OW Hydrogen induced trap states in $\mathrm{TiO}_{2}$ probed by resonant X-ray photoemission [11886-18] 
11886 OX Dual spectrometer for simultaneous visible and extreme ultraviolet LIBS [1 1886-37]

11886 OY Short-wavelength Raman spectroscopy for in-situ water analysis: a feasibility study [1 1886-40]

$118860 Z$ Imaging isotopic content at the nanoscale using extreme ultraviolet laser ablation and ionization mass spectrometry [11886-15]

1188610 Time-of-flight mass spectrometry to determine plasma temperature from ablated target surfaces [11886-24]

1188611 Transient laboratory X-ray absorption fine structure spectroscopy on thin films demonstrated with F8BT [1 1886-13]

$1188612 \quad$ Ultrafast NEXAFS spectroscopy in the lab using laser-based sources and advanced X-ray optics [11886-35]

$1188613 \quad X$-ray imaging of human brain tissue down to the molecule level [1 1886-6]

$1188614 \quad$ Hard X-ray microtomography of Zebrafish larvae [11886-11]

$1188615 \quad$ Study of sodium depositions in heart interstitium using methods of X-ray absorption and fluorescent microscopy [11886-36] 
Proc. of SPIE Vol. 11886 1188601-6 Downloaded From: https://www.spiedigitallibrary.org/conference-proceedings-of-spie on 26 Apr 2023
Terms of Use: https://www.spiedigitallibrary.org/terms-of-use 